\title{
The Secreted $\beta$-Amyloid Precursor Protein Ectodomain APPs $\alpha$ Is Sufficient to Rescue the Anatomical, Behavioral, and Electrophysiological Abnormalities of APP-Deficient Mice
}

\author{
Sabine Ring, ${ }^{1,2}$ Sascha W. Weyer, ${ }^{1}$ Susanne B. Kilian, ${ }^{3}$ Elaine Waldron, ${ }^{4}$ Claus U. Pietrzik, ${ }^{4}$ Mikhail A. Filippov,,${ }^{1,2}$ \\ Jochen Herms, ${ }^{5}$ Christian Buchholz, ${ }^{6}$ Christopher B. Eckman, ${ }^{7}$ Martin Korte, ${ }^{3}$ David P. Wolfer,${ }^{8}$ and Ulrike C. Müller ${ }^{1,2}$ \\ ${ }^{1}$ Department of Bioinformatics and Functional Genomics, Institute for Pharmacy and Molecular Biotechnology, University of Heidelberg, D-69120 \\ Heidelberg, Germany, ${ }^{2}$ Department of Neurochemistry, Max Planck Institute for Brain Research, D-60598 Frankfurt, Germany, ${ }^{3}$ Zoological Institute, \\ Technical University Braunschweig, D-38106 Braunschweig, Germany, ${ }^{4}$ Department of Molecular Neurodegeneration, Institute of Physiological Chemistry \\ and Pathobiochemistry, University of Mainz, D-55099 Mainz, Germany, ${ }^{5}$ Center for Neuropathology and Prion Research, München University, D-81377 \\ München, Germany, ${ }^{6}$ Paul Ehrlich Institute, D-63225 Langen, Germany, ${ }^{7}$ Mayo Clinic, Jacksonville, Florida 32224, and ${ }^{8}$ Institute of Anatomy, University of \\ Zürich and Department of Biology, Eidgenössische Technische Hochschule Zürich, CH-8057 Zürich, Switzerland
}

It is well established that the proteolytic processing of the $\beta$-amyloid precursor protein (APP) generates $\beta$-amyloid (A $\beta$ ), which plays a central role in the pathogenesis of Alzheimer's disease (AD). In contrast, the physiological role of APP and of its numerous proteolytic fragments and the question of whether a loss of these functions contributes to AD are still unknown. To address this question, we replaced the endogenous APP locus by gene-targeted alleles and generated two lines of knock-in mice that exclusively express APP deletion variants corresponding either to the secreted APP ectodomain (APPs $\alpha$ ) or to a C-terminal (CT) truncation lacking the YENPTY interaction motif (APP $\triangle \mathrm{CT} 15)$. Interestingly, the $\triangle \mathrm{CT} 15$ deletion resulted in reduced turnover of holoAPP, increased cell surface expression, and strongly reduced $A \beta$ levels in brain, likely because of reduced processing in the endocytic pathway. Most importantly, we demonstrate that in both APP knock-in lines the expression of APP N-terminal domains either grossly attenuated or completely rescued the prominent deficits of APP knock-out mice, such as reductions in brain and body weight, grip strength deficits, alterations in circadian locomotor activity, exploratory activity, and the impairment in spatial learning and long-term potentiation. Together, our data suggest that the APP C terminus is dispensable and that APPs $\alpha$ is sufficient to mediate the physiological functions of APP assessed by these tests.

Key words: Alzheimer's disease; $\beta$-amyloid precursor protein; APPs $\alpha$; physiological functions; knock-out; LTP

\section{Introduction}

One of the hallmarks of Alzheimer's disease $(\mathrm{AD})$ is the deposition of the $\beta$-amyloid peptide $(\mathrm{A} \beta)$, derived from the $\beta$-amyloid precursor protein (APP), in the brains of $\mathrm{AD}$ patients (Selkoe, 2004). Whereas the mechanisms governing $A \beta$ generation have been studied intensely, the physiological role of APP and the question of whether a loss of these functions contributes to $\mathrm{AD}$ remain unclear.

Two major obstacles complicate the analysis of APP functions in vivo. First, because APP is a member of a gene family including

\footnotetext{
Received March 7, 2007; revised June 6, 2007; accepted June 7, 2007.

This work was supported by Deutsche Forschungsgemeinschaft Grant MU1457/4-3 (U.C.M.), Bundesministerium für Bildung und Forschung Grant 01 GS0469 (U.C.M.), and grants from the Thyssen Foundation (to U.C.M. and M.K.), the Swiss National Science Foundation, and the National Center of Competence in Research, Neural Plasticity and Repair. We thank Heinrich Betz for continuous support; Paul Mathews for advice regarding APPs $\alpha$ detection; Bart De Strooper for providing the B63 antibody; Jakob Tschäpe for help with art work; and Nicole Fürst, Franziska Stöcklin, and Inger Drescher for excellent technical assistance.

Correspondence should be addressed to Ulrike Müller at the above address. E-mail: u.mueller@urz.uni-hd.de. DOI:10.1523/JNEUROSCI.1026-07.2007

Copyright $\odot 2007$ Society for Neuroscience $\quad 0270-6474 / 07 / 277817-10 \$ 15.00 / 0$
}

APP-like proteins (APLPs) APLP1 and ALPL2, functional redundancy may compensate for the loss of essential gene functions, e.g., in knock-out (KO) models. Indeed, the extensive structural similarities between APP and APLPs are also reflected at the functional level (Anliker and Müller, 2006). Previously, we and others documented that APP-KO mice exhibit growth and brain weight deficits, reduced grip strength, agenesis of the corpus callosum, hypersensitivity to seizures, defects in copper and lipid homeostasis, altered locomotor activity, and impaired spatial learning associated with impaired long-term potentiation (LTP) (Müller et al., 1994; Zheng et al., 1995; Li et al., 1996; Steinbach et al., 1998; Tremml et al., 1998; Dawson et al., 1999; Magara et al., 1999; Seabrook et al., 1999; White et al., 1999; Grimm et al., 2005). Like APP-KO mice, APLP-deficient mice proved viable, whereas combined APP ${ }^{-/-}$APLP2 ${ }^{-/-}$or APLP1 $1^{-/-} \mathrm{APLP}^{-/-}$ double KO (von Koch et al., 1997; Heber et al., 2000) and $\mathrm{APP}^{-1-}$ APLP1 $1^{-1-} \mathrm{APLP} 2^{-1-}$ triple mutants die postnatally, the latter exhibiting cranial dysplasias resembling human type II lissencephaly (Herms et al., 2004).

Second, functional diversity also may result from proteolytic 
processing of APP, leading to diverse extracellular and intracellular APP fragments (for review, see Selkoe, 2004). APP is a type I transmembrane protein and cleaved either by $\alpha$-secretase within the $\mathrm{A} \beta$ region or by $\beta$-secretase at the $\mathrm{N}$ terminus of $\mathrm{A} \beta$, leading to the secretion of the large soluble ectodomains APPs $\alpha$ and $\mathrm{APPs} \beta$. Intramembrane processing of $\beta$-secretase-cleaved APP C-terminal fragments by $\gamma$-secretase results in the production of $A \beta$ and the APP intracellular domain (AICD). APPs $\alpha$ has been implicated in various cellular processes including neuroprotection, may serve a memory-enhancing function, and regulates neuronal excitability and synaptic plasticity (Turner et al., 2003; Reinhard et al., 2005; Zheng and Koo, 2006). Recently, the AICD has been shown to form a complex with Fe65/Tip60 and might regulate transcription (for review, see Selkoe, 2004). The nature of potential target genes, however, is still under debate (Hebert et al., 2006; Zheng and Koo, 2006). Most of the identified binding partners of APP interact with the cytoplasmic tail. Notably, the YENPTY motif that is conserved from Caenorhabditis elegans to mammalian APP/APLPs confers clathrin-mediated endocytosis and has been shown to bind several kinases as well as adaptor proteins, including mouse disabled homolog 1 (mDab1), Jun N-terminal kinase-interacting protein (JIP), X11/mints, and Fe65 family proteins. Although in vitro studies have shown that these interactions not only may modulate APP processing but also may mediate cell signaling, the in vivo relevance for both processing and physiology is still mainly unknown.

Here we have generated by gene targeting two lines of knock-in mice (KI) expressing different truncated APP variants. We introduced stop codons such that APPs $\alpha$-KI mice express only secreted APPs $\alpha$ and APP $\Delta$ CT15-KI mice lack the last 15 aa. These mice allowed us to test the requirement of different domains of APP for its physiological function. Here we report that the secreted APPs $\alpha$ domain is sufficient to rescue prominent abnormalities of APP-KO mice, including reductions in brain and body weight, grip strength deficits, and the impairment in spatial learning and LTP. Collectively, our data suggest that APPs $\alpha$ is sufficient to mediate the (postnatal) physiological functions of APP assessed by these tests.

\section{Materials and Methods}

Generation of mutant APPsa-KI and APPDCT15-KI embryonic stem cells and mice. The vector pEasyFlox was used as a backbone, and the arms of homology were inserted as detailed in the supplemental material (available at www.jneurosci.org). Electroporation and selection of embryonic stem (ES) cells was performed as previously described (Heber et al., 2000). Southern blotting was performed by using standard techniques, probing with a $0.6 \mathrm{~kb}$ PCR-generated fragment. Positive clones were identified and injected into blastocysts to generate germline-transmitting chimeras.

Quantitative PCR. Total RNA was prepared from whole brains of 6- to 12-week-old mice, and quantitative real-time PCR was done as detailed in the supplemental material (available at www.jneurosci.org), using TaqMan probes overlapping the APP exon 9-10 boundary.

Tissue processing and Western blot analysis. Western blot analysis of whole-brain homogenates of 6- to 12-week-old APPs $\alpha$-KI and APP $\Delta$ CT15-KI animals and wt littermates was performed as previously described (Heber et al., 2000). The fractionation of soluble APPs and cell-bound APP was performed as detailed in the supplemental material (available at www.jneurosci.org). Western blot signals were detected by enhanced chemiluminescence (Super Signal West Pico; Pierce, Rockford, IL); scanned and digitalized images were analyzed for quantification with AIDA (Advanced Image Data Analysis) software (Raytest USA, Wilmington, NC). Additional details are given in the supplemental material (available at www.jneurosci.org).

Antibodies. For Western blots specific antibodies directed against the
APP N terminus (22C11; 1:5000; Chemicon, Temecula, CA), the APP C terminus (B63; 1:1000), APLP1 (CT11; 1:1000; Calbiochem, La Jolla, CA), APLP2 (D2II; 1:2000; Calbiochem), and $\beta$-tubulin (MAB3408; 1:10,000; Chemicon) were used. For immunoprecipitation we used the polyclonal antibody $A \beta N T$, generated by immunizing rabbits with a peptide corresponding to the first 15 aa of murine $\mathrm{A} \beta$.

Cell lines and metabolic labeling. Mouse fibroblasts derived from APPs $\alpha$-KI, APP $\Delta$ CT15-KI, and wt littermates were obtained from embryonic day 14.5 embryos and immortalized with SV40Tag, using a retroviral vector. Details of metabolic labeling are given in the supplemental material (available at www.jneurosci.org).

$A \beta$ measurements. Mouse brains (age 9-12 months) were homogenized in 9 volumes of $0.2 \%$ diethylamine in $50 \mathrm{~mm} \mathrm{NaCl}$, using a Potter homogenizer. Homogenates were centrifuged at $100,000 \times g$ for $1 \mathrm{~h}$, and the supernatant was neutralized with a 1:10 volume of $50 \mathrm{~mm}$ Tris- $\mathrm{HCl}$, $\mathrm{pH}$ 6.8. $\mathrm{A} \beta \mathrm{x}-40$ and $\mathrm{A} \beta \mathrm{x}-42$ ELISAs were performed by using the BNT77/BA-27 (A $\beta \mathrm{x}-40)$ and BNT-77/BC-05 (A $\beta \mathrm{x}-42)$ system (Duff et al., 1996).

Behavioral analysis. All behavioral procedures were approved by Swiss animal welfare authorities. Mice were housed in single cages and allowed to adapt to a reverse light cycle (lights off at 8:00 A.M.; on at 8:00 P.M.) for at least 1 week so that they could be tested during the dark phase of the cycle. A total of 94 mice $(n=13-17$ per genotype), distributed over three cohorts (each containing approximately balanced numbers of male and female mice), were analyzed in a blinded manner in the following order of tests: water maze (age 2.42 \pm 0.02 months), grip test (age $2.64 \pm 0.02$ months), light/dark box (age $3.2 \pm 0.15$ months), home cage activity recording (age $8.01 \pm 0.14$ months).

Home cage activity. Home cage activity was recorded as described previously (Madani et al., 2003) with the use of a cage rack equipped with one passive infrared sensor per mouse (ActiviScope; New Behavior, Zurich, Switzerland). The sensors detected any locomotion and remained silent only when the mice were sleeping or grooming. Recording started after a habituation period of at least $18 \mathrm{~h}$, and circadian profiles were calculated by averaging data from at least 4 recording days.

Spatial learning, light/dark box, and grip strength tests. Place navigation, light/dark box, and grip strength were measured as detailed in the supplemental material (available at www.jneurosci.org).

Electrophysiology. In vitro extracellular recordings were performed on acute hippocampal slices of individuals characterized behaviorally. The following animals were studied: APP-KO, $n=6$, and wt littermates, $n=$ 5 (age 9-12 months); APPs $\alpha$-KI, $n=4$, and wt littermates, $n=5$ (12-15 months); APP $\Delta$ CT15-KI, $n=6$, and wt littermates, $n=4$ (age 12-15 months). Details on slice preparation and electrophysiology are given as supplemental material (available at www.jneurosci.org).

\section{Results}

\section{Generation of APPs $\alpha$-KI and APP $\Delta$ CT15-KI mice}

Transgenic approaches based on random integration of expression vectors may fall short of matching the endogenous spatiotemporal expression pattern because of the modulating effects of neighboring chromatin regions. Therefore, we used gene targeting in ES cells to replace the endogenous APP locus with modified APP alleles. We generated two lines of KI mice that express under control of the endogenous chromosomal APP promoter either exclusively (1) APPs $\alpha$ or (2) APP $\Delta$ CT15, a C-terminal deletion mutant lacking the last 15 aa of APP harboring the YENPTY motif. Using the targeting strategy depicted in Figure 1, we have introduced a stop codon into APP exon 16 behind the $\alpha$-secretase site at position QK612, flanked by a SV40 polyA site to ensure efficient polyadenylation of the mRNA (APPs $\alpha$-KI). We have chosen as the long arm of homology an intronic fragment downstream of exon 17 to guarantee that homologous recombination also will result in a deletion of the endogenous APP transmembrane domain encoded by exon 17 (Fig. $1 B$ ). It should be noted that because of the knock-in approach APP-truncated variants can be studied on an APP null background, that these variants are 
A

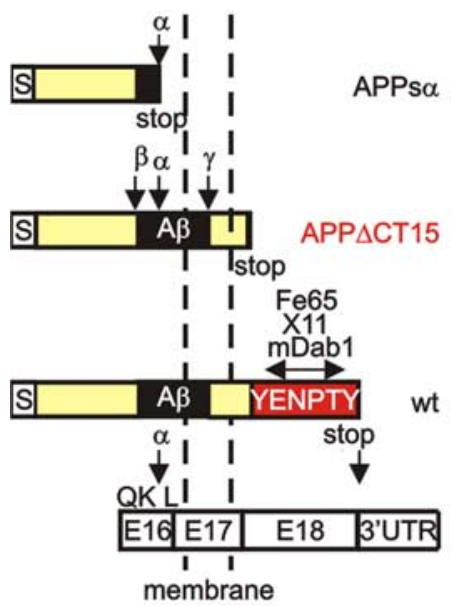

C

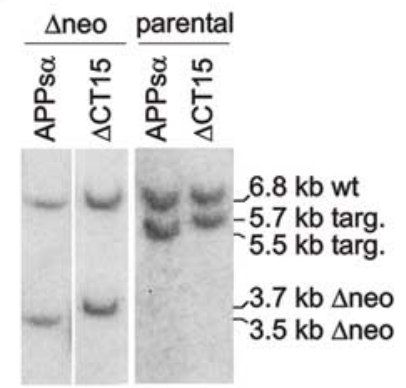

B
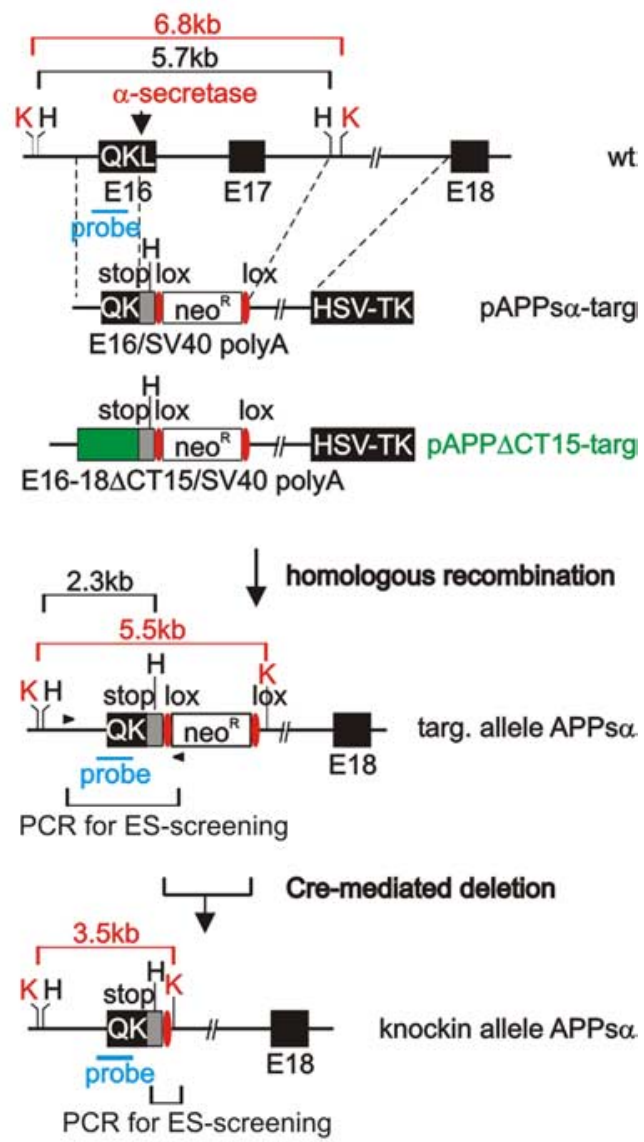

$E$

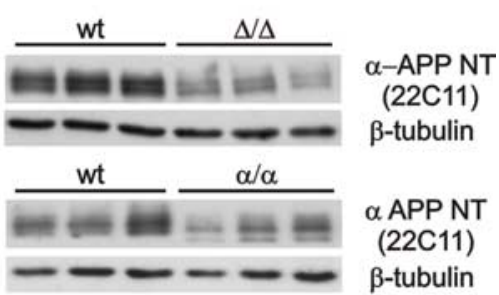

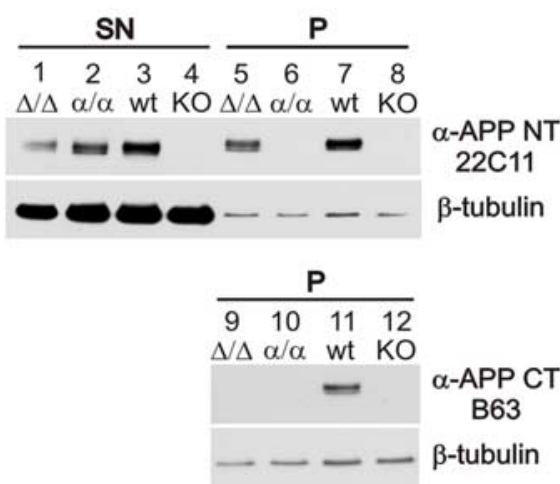

Figure 1. Generation of knock-in mice. A, Schematic representation (not to scale) of APP-KI variants APPs $\alpha$-KI and APP $\Delta C T 15-K L$. Open boxes represent exons (E16, E17, E18) encoding the APP C terminus; S, signal peptide. $B$, The short arm of pAPPs $\alpha$-targ encompasses exon 16 into which a stop codon was introduced behind the $\alpha$-secretase site. In pAPP $\Delta$ CT15-targ the coding sequence of exon 16 was fused to $\mathrm{APP}_{695}{ }^{-} \mathrm{CDNA}$ sequences up to amino acid 680 ( $\mathrm{E} 16-18 \Delta \mathrm{CT} 15$; green box) flanked by a stop codon. The stop codon was followed by a SV40 polyA site (gray box) and a floxed neo gene for selection in ES cells. The long arm of homology consists of a $6.2 \mathrm{~kb}$ intronic fragment downstream of exon 17. Subsequently, the neo gene was deleted by transient expression of Cre-recombinase $(\boldsymbol{B}$, bottom). K, Kpnl; H, Hindlll. C, Correct gene targeting and removal of the neo gene ( $\Delta$ neo) was confirmed by Southern blotting with a $0.6 \mathrm{~kb}$ probe overlapping exon 16 (B, probe). Kpnl digestion of ES cell DNA revealed expected bands of $6.8 \mathrm{~kb}$ (wt), $3.5 \mathrm{~kb}$ (APPs $\alpha$-allele), and $3.7 \mathrm{~kb}$ (APP $\Delta$ CT15 allele). D. Western blot analysis (N-terminal antibody 22C11) of soluble APPs and membrane-bound holoAPP from adult brain revealed in pellet fractions (P) from wt mice the typical set of bands expected for holoAPP (lane 7) and a similar set of bands for APP $\Delta$ CT15-KI mice (lane 5). No membrane-bound APP was detected in pellet fractions of APPs $\alpha$-KI mice (lane 6). In supernatant fractions (SN) soluble APPs derived from APPs $\alpha$-KI brain c0-migrated with APPs produced in wt or APP $\Delta$ CT15-KI brains (lanes 1-3). As expected, no signal was detectable with a C-terminal antibody for either KI variant (lanes 9, 10). As a negative control APP-KO brain was used (lanes 4, 8, 12), and $\beta$-tubulin staining was performed to monitor loading. $E$, Western blot analysis of wholebrain homogenates of APP-KI mutants (25 $\mu \mathrm{g}$ of protein/lane), using an N-terminal anti-APP antibody (22C11). Note that quantification revealed for APP $\triangle$ CT15-KI brain a significant reduction of APP expression. A similar, but not significant, trend was observed for APPs $\alpha$-KI mice (see Results for details).

expressed by the endogenous promoter, and that all splice sites are unaffected by our strategy, thus leading to the expression of the endogenous pattern of APP isoforms.

To generate APP $\triangle \mathrm{CT} 15-\mathrm{KI}$ mice, we fused the coding sequence of APP exon 16 to $\mathrm{APP}_{695} \mathrm{-cDNA}$ sequences up to amino acid 680 , followed by a stop codon (Fig. $1 B$, middle). Homologous recombination events were identified by PCR and confirmed by Southern blot analysis, using KpnI-digested DNA (Fig. 1C). The resulting mutant ES cells were injected into blastocysts and gave rise to germline-transmitting chimeras. Intercrosses of heterozygous APPs $\alpha$-KI and APP $\Delta$ CT15-KI mice led to homozygous mutant animals at the expected Mendelian frequencies.

\section{Expression of APP-KI variants and $\mathrm{A} \boldsymbol{\beta}$ generation}

The primary goal of this study was to assess which domains of APP are crucial for its in vivo function(s). To this end we first examined the expression of APP-KI variants from the gene-targeted loci. Western blot analysis of soluble APPs and membrane-bound holoAPP from adult homozygous KI mice is depicted in Figure 1D. Incubation with an anti-APP antibody (22C11) directed against an $\mathrm{N}$-terminal epitope revealed in pellet fractions from wt mice the typical set of bands expected for holoAPP (corresponding to immature and glycosylated mature APP) and a similar set of bands for APP $\Delta$ CT15-KI mice (Fig. $1 D$, lanes 5, 7). Because of the minor difference in molecular weight no apparent size difference was resolvable between the wt and the APP $\triangle$ CT15 protein variant. Notably, for APPs $\alpha$-KI mice no membrane-bound APP was detected in pellet fractions (Fig. $1 D$, lane 6 ), whereas in supernatant fractions soluble APPs derived from APPs $\alpha$-KI brain was prominently expressed and co-migrated with APPs produced in wt or APP $\triangle$ CT-KI brains (Fig. $1 D$, lanes $1-3$ ). This indicates that, although not generated by $\alpha$-secretase processing of holoAPP, APPs $\alpha$ can be produced and secreted in KI brains at high levels. Importantly, no signal could be detected with an antibody raised against the APP C terminus for either KI variant (Fig. $1 D$, lanes 9, 10), indicating a deletion of this epitope and corroborating the functionality of the knock-in approach.

We examined expression levels of mutant APP in APP-KI brains at the mRNA and protein levels. To assess whether introduction of the SV40 polyA cassette might have altered the steady-state level of APP mRNA in KI mice, we performed quantitative realtime PCR on whole-brain RNA of adult 
mice (6-12 weeks of age), which indicated that mRNA levels were reduced to $65 \pm 12 \%(p<0.001$; Student's $t$ test $)$ in APP $\Delta$ CT15 mutants and to $67 \pm 10 \%(p<0.001$; Student's $t$ test $)$ in APPs $\alpha$ mice as compared with wt littermates. Similarly, Western blot analysis of APP from whole-brain homogenates (without additional fractionation) (Fig. $1 E$ ) revealed for APP $\Delta$ CT15-KI mice a reduction to $\sim 57 \pm 11 \%$ of wt littermate levels $(p<0.001$; Student's $t$ test). For APPs $\alpha$-KI mice a similar trend was observed; however, differences did not reach statistical significance ( $p \geq 0.05$; Student's $t$ test). For all samples APP expression levels were normalized to $\beta$-tubulin stainings. Thus the reduced expression of the APP-KI protein variants can be attributed mainly to reduced APPs $\alpha$ and APP $\Delta$ CT15 mRNA levels, which may be due to the SV40 polyA cassette. Expression of the related APP family members APLP1 and APLP2 was unaltered in both KI mutants (data not shown), indicating no compensatory upregulation.

We then investigated whether the deletion of the C-terminal $15 \mathrm{aa}$ (containing a prominent protein interaction motif as well as an endosomal internalization site) affects endogenous APP processing and analyzed $\mathrm{A} \beta$ levels in whole-brain extracts by sandwich ELISA. Because APP $\Delta$ CT15 protein variants were expressed at reduced levels, we corrected the raw values accordingly. Nevertheless, APP $\Delta$ CT15-KI mice showed a reduction of A $\beta 40$ to $34 \pm 16 \%(p<0.001$; Student's $t$ test $)$ of wt littermate level. Likewise, $\mathrm{A} \beta 42$ levels were reduced similarly to $44 \pm 8 \%$ ( $p<$ 0.001 ; Student's $t$ test). To assess whether reduced $\mathrm{A} \beta$ generation is attributable to reduced processing by the endocytic pathway, we studied the turnover of endogenous full-length APP by metabolic labeling. Mouse embryonic fibroblasts (MEFs) derived from wt or APP $\Delta$ CT15-KI mice were pulse-labeled for $15 \mathrm{~min}$ and chased for $0,30,60,90,120,180$, and $360 \mathrm{~min}$. APP was recovered by immunoprecipitation with $\mathrm{A} \beta \mathrm{NT}$, an antibody directed against the $\mathrm{N}$ terminus of the murine $\mathrm{A} \beta$ region. Whereas wt APP showed a half-life of $\sim 60 \mathrm{~min}$ (Fig. $2 A$ ), the turnover of APP $\Delta$ CT15 from mutant MEFs was reduced markedly, as revealed by a prolonged half-life of $\sim 90 \mathrm{~min}$ (Fig. $2 \mathrm{~A}$ ). To assess the cell surface pool of APP directly, we performed biotinylation experiments. Indeed, APP surface expression in APP $\Delta$ CT15 MEFs was $\sim 2.5$-fold increased as compared with APP wt MEFs (Fig. $2 B)$. Together, our data obtained with the APP $\Delta$ CT15 variant expressed from the endogenous APP locus are consistent with previous studies that used similar APP mutants in transfected cell lines (Perez et al., 1999) and suggest that reduced endocytosis leads to reduced amyloidogenic processing.

\section{The growth and brain weight deficit of APP-KO mice is rescued in APP-KI mice}

Finally, we addressed the primary question of whether the phenotype of APP-KI mice would be identical to that of APPdeficient mice (which would indicate a requirement of the APP $\mathrm{C}$ terminus and/or anchorage within the membrane) or whether and to what extent the APP deletion variants might rescue the various deficits of APP-KO mice. Previous analysis of APP-KO mice had revealed a phenotype characterized by the following features: (1) reduced postnatal brain and body weight, (2) behavioral abnormalities such as reduced grip strength and locomotor alterations, and (3) reduced spatial learning associated with an LTP deficit in aged mice (Müller et al., 1994; Zheng et al., 1995; Li et al., 1996; Dawson et al., 1999; Magara et al., 1999; Seabrook et al., 1999). For all studies the APP-KO, APPs $\alpha$-KI, APP $\Delta$ CT15-KI mice, and their respective wt littermate controls were obtained
A
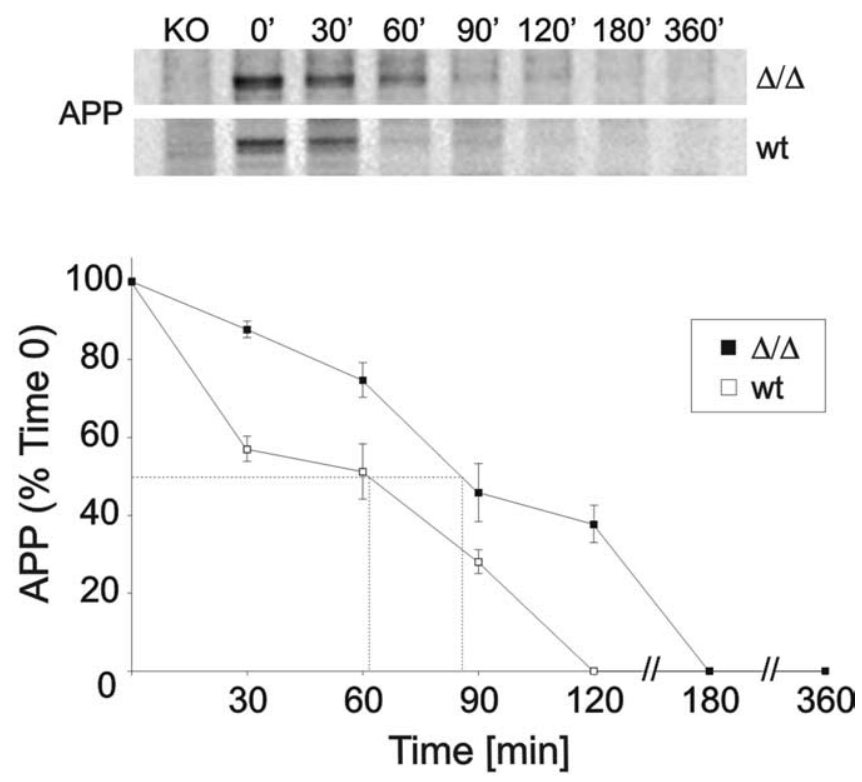

B

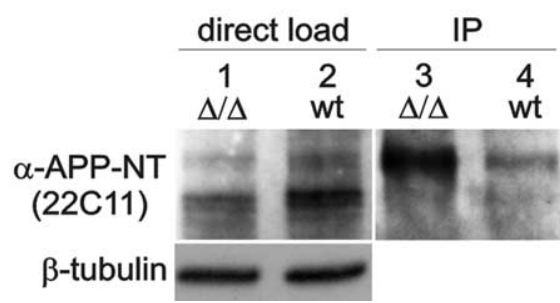

Figure 2. Turnover of full-length APP and cell surface expression. $A$, Turnover of endogenous cell-bound APP. APP $\Delta$ CT15-KI and wt MEFs were pulse-labeled with $\left[{ }^{35} \mathrm{~S}\right]$ methionine/cysteine for $15 \mathrm{~min}$ and chased for the indicated time intervals. At time 0 , APP consists predominantly of immature $\mathrm{N}$-glycosylated species. Both the $\mathrm{N}$-glycosylated and mature $\mathrm{N}$ - and $\mathrm{O}$-glycosylated species are abundant at $30 \mathrm{~min}$ for both cell types. After a $60-90$ min chase period the APP level is reduced dramatically in wt MEFs and below detection level at $120 \mathrm{~min}$. In contrast, in APP $\Delta$ CT15-KI MEFs the APP expression is reduced to only $40 \%$ after a 120 min chase period. Half-life was determined by quantitating the results as indicated by dotted lines $(\boldsymbol{B})$. All values are presented as the means \pm SEM. Differences were detected with two-tailed Student's t test, accepting $p<0.05$ as significant. $\boldsymbol{B}$, Biotinylation of surface APP. APP $\Delta$ CT15-KI and wt MEFs were surface-biotinylated for $30 \mathrm{~min}$. Cell lysate (15 $\mu \mathrm{g} /$ /ane) was loaded directly onto a 10\% Tris-tricine gel (lanes 1, 2) or was immunoprecipitated ( $350 \mu \mathrm{g} /$ immunoprecipitate) by using NeutrAvidin-agarose beads (lanes 3, 4). APP was detected with the use of an N-terminal antiAPP antibody (22C11), revealing a considerable increase of surface APP in APP $\triangle$ CT15-KI cells when compared with wt controls.

from heterozygous intercrosses (e.g., $\mathrm{APP}^{+/-} \times \mathrm{APP}^{+/-}$; $\left.\mathrm{APP}^{\alpha /+} \times \mathrm{APP}^{\alpha /+}\right)$.

We have shown previously that APP-KO mice show a postnatal somatic growth deficit that emerges in the second postnatal week and is maximal at 4 weeks postnatally. Here the brain and body weights were analyzed in parallel to the various behavioral tests. Body weights were studied at 2.4 months of age, and we observed a reduction of $\sim 15 \%$ in female and $19 \%$ in male APP-KO mice (Fig. 3A), thus confirming our previous results (Müller et al., 1994; Magara et al., 1999). In contrast, not only APP $\Delta$ CT15-KI mice but also the APPs $\alpha$-KI line showed normal body weights (Fig. 3A). Brain weights were determined after completion of the behavioral analysis at 10-12 months of age. As expected, APP-KO mice displayed a strong reduction of wet brain weight by $11 \%$ (Fig. $3 B$ ). This effect was corrected completely in 
APP-KO

APP $\triangle \mathrm{CT} 15-\mathrm{KI}$

$\mathrm{APPs} \alpha-\mathrm{KI}$

A
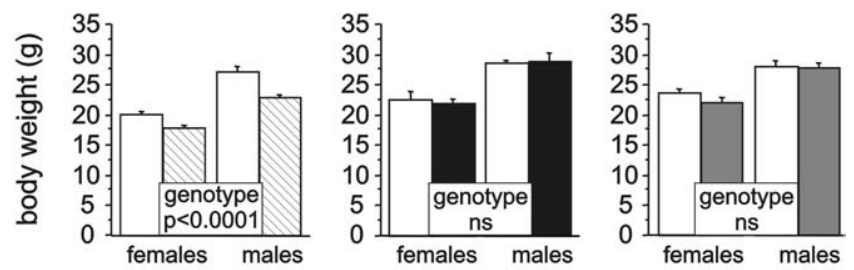

B
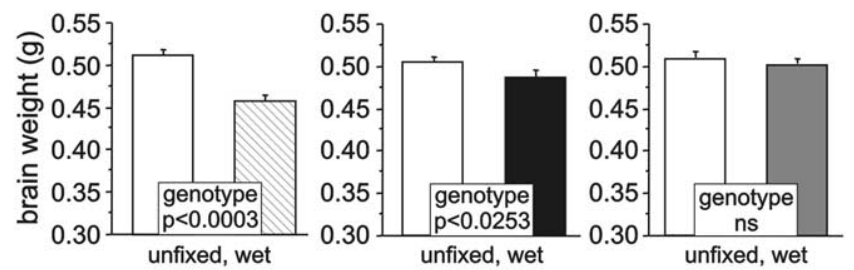

C
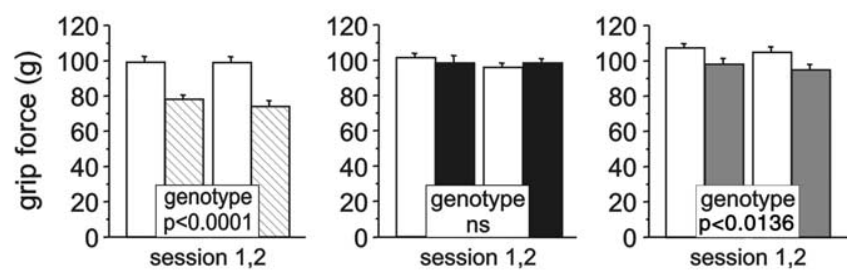

O wt littermates OAPP-KO APP $\triangle \mathrm{CT} 15-\mathrm{KI}$ OAPPs $\alpha-\mathrm{KI}$

Figure 3. Somatic development and grip strength. $A$, Body weight measured at 2.4 months before water maze testing was reduced in APP-KO (13 KO and $15 \mathrm{wt}$ ) regardless of gender, but not in APP $\Delta$ CT15-KI (17 KI and $16 \mathrm{wt}$ ) nor in APPs $\alpha$-KI (17 KI and $16 \mathrm{wt})$ mice. ANOVA: genotype $\times$ line, $F_{(2,58)}=5.1(p<0.0092)$; genotype $\times$ line $\times$ gender, $F_{(2,58)}=1.3$, ns. APP-KO: genotype, $F_{(1,16)}=31.2(p<0.0001)$; genotype $\times$ gender, $F_{(1,16)}=2.7$, ns. APP $\Delta$ CT15-Kl: genotype, $F_{(1,21)}=0.1$, ns; genotype $\times$ gender, $F_{(1,21)}=0.1$, ns. APPs $\alpha$-KI: genotype, $F_{(1,21)}=0.7$, ns; genotype $\times$ gender, $F_{(1,21)}=0.8$, ns. $\boldsymbol{B}$, Brain weight at $10-12$ months of age was strongly reduced in APP-KO mice ( $9 \mathrm{KO}$ and $10 \mathrm{wt}$ ). This effect was attenuated in the APP $\Delta$ CT15-KI (12 KI and $10 \mathrm{wt}$ ) and fully corrected in the APPs $\alpha$-KI line (12 KI and $10 \mathrm{wt}$ ). ANOVA: genotype $\times$ line, $F_{(1,29)}=4.9(p<0.0151)$. APP-K0: genotype, $F_{(1,9)}=31.4$ $(p<0.0003)$. APP $\Delta$ CT15-KI: genotype, $F_{(1,12)}=6.5$ ( $\left.p<0.0253\right)$. APPs $\alpha$-KI: genotype, $F_{(1,8)}=0.3$, ns. C, Grip strength was strongly reduced in APP-K0 mice (13 KO and $15 \mathrm{wt}$ ) in both test sessions on consecutive days. This effect was fully corrected in the APP $\Delta C T 15-\mathrm{KI}$ (17 KI and $16 \mathrm{wt})$ and attenuated in the APPs $\alpha$-KI line (17 KI and $16 \mathrm{wt}$ ). ANOVA: genotype $\times$ line, $F_{(2,58)}=9.0(p<0.0004)$; genotype $\times$ line $\times$ session, $F_{(2,58)}=0.7$, ns. APP-KO: genotype, $F_{(1,16)}=52.4(p<0.0001)$; genotype $\times$ session, $F_{(1,16)}=0.7$, ns. APP $\Delta$ CT15-KI: genotype, $F_{(1,21)}=0.4$, ns; genotype $\times$ session, $F_{(1,21)}=0.3$, ns. APPs $\alpha$-Kl: genotype, $F_{(1,21)}=7.3$ $(p<0.0136)$; genotype $\times$ session, $F_{(1,21)}=1.3$, ns.

the APPs $\alpha$-KI line and grossly attenuated in the APP $\Delta$ CT15-KI mutants, who displayed a reduction by $3.6 \%$ (Fig. $3 B$ ). Likewise, histopathological analysis of $\mathrm{KO}$ and $\mathrm{KI}$ mutants (as assessed by cresyl violet, hematoxylin/eosin, synaptophysin, mitogenactivated protein kinase 2, and glial fibrillary acidic protein staining at 11 months) did not show any apparent abnormalities as compared with wt littermate controls (data not shown).

\section{APP-KI mutants rescue the grip strength deficit, altered circadian locomotor activity, exploratory activity, and learning deficit of APP-KO mice}

First we assessed a potential grip strength deficit in KI mice, because we had previously observed this as a robust abnormality of
APP-KO mutants. As predicted, APP-KO mice revealed, on average, a grip strength deficit of $23 \%$ (Fig. $3 C$ ). In the APP $\Delta$ CT15-KI line grip strength was not statistically different from wt littermates, and APPs $\alpha$-KI mice showed a slight deficit of 9.2\% (Fig. 3C).

Spontaneous home cage activity was monitored after habituation in individual cages equipped with infrared sensors (Madani et al., 2003). APP-KO mice showed massively overshooting activity during the beginning of the dark phase but were less active than wt controls toward the end of the dark phase. In contrast, levels and circadian distribution of activity of both KI mutants were indistinguishable from controls (Fig. 4A). We also analyzed mice in the light/dark box paradigm that assesses potential differences toward aversive stimuli and exploratory activity. Regardless of genotype and line, all mice spent significantly more than $50 \%$ of their time in the dark compartment of a light/dark box, confirming the aversiveness of the brightly illuminated compartment (data not shown). The number of transitions between the two compartments was significantly smaller in APP-KO mice, indicative of reduced exploratory activity under aversive conditions. This effect was corrected fully in both KI lines (Fig. 4B).

Spatial navigation was assessed in a water maze place navigation task that included an acquisition phase as well as a reversal phase, with the platform moved to the opposite quadrant. APP-KO mice performed similarly to controls at the beginning but took approximately twice as long to find the platform toward the end of acquisition training and also were impaired during most of the reversal phase (Fig. 4C). Only at the very end of training did they reach a performance level similar to controls. No such impairment was observed in KI lines (Fig. 4C). Swim speed was reduced in APP-KO mice by $19 \%$ (13 KO $0.168 \pm$ $0.008 \mathrm{~m} / \mathrm{s} ; 15 \mathrm{wt}, 0.207 \pm 0.007 \mathrm{~m} / \mathrm{s}$; genotype, $F_{(1,16)}=15.7 ; p<$ $0.001)$, reflecting the muscle weakness already evident from grip strength deficits. The KI lines showed only minor, but not significant, reductions, with APP $\Delta$ CT15-KI being $4.6 \%$ slower than controls [17 KI, $0.228 \pm 0.006 \mathrm{~m} / \mathrm{s} ; 16 \mathrm{wt}, 0.239 \pm 0.007 \mathrm{~m} / \mathrm{s}$; genotype, $F_{(1,21)}=3.8$, not significant (ns)] and APPs $\alpha$-KI being $9.0 \%$ slower than controls $(17 \mathrm{KI}, 0.214 \pm 0.008 \mathrm{~m} / \mathrm{s} ; 16 \mathrm{wt}$, $0.235 \pm 0.008 \mathrm{~m} / \mathrm{s}$; genotype, $\left.F_{(1,21)}=4.1, \mathrm{~ns}\right)$. The amount of time spent floating passively was very small $(1.42 \pm 1.12 \mathrm{~s})$ and did not differ across groups. The swim speed reduction of APP-KO mice accounted only partially for their performance deficit during training, as evidenced by the fact that they also swam considerably longer distances to find the platform (Fig. $4 D$ ) and also were impaired according to speed-insensitive measures of spatial accuracy such as Whishaw's error (average percentage path outside the beeline corridor) $(\mathrm{KO}, 80.3 \pm 1.1 \%$; wt, $\left.76.0 \pm 1.3 \% ; F_{(1,16)}=4.8 ; p<0.0442\right)$. In contrast, APP $\Delta$ CT15-KI were unimpaired according to swim path length (Fig. 4D) and also earned Whishaw's error scores typical for the genetic background used in this study (KI, $75.2 \pm 1.4 \%$; wt, $73.6 \pm 1.7 \%$; genotype, $F_{(1,21)}=1.2$, ns). Similarly, APPs $\alpha$-KI showed path lengths (Fig. 4D) and Whishaw's error scores (KI, $72.6 \pm 1.9 \%$; wt, $77.8 \pm 1.3 \%$; genotype, $F_{(1,21)}=2.3$, ns) indistinguishable from controls. The reduced training performance of APP-KO mice may be explained at least in part by wall hugging, which was increased on average by $100 \%$ in APP-KO mice $(\mathrm{KO}$, $15.0 \pm 4.0 \%$; wt, $\left.7.3 \pm 1.1 \% ; F_{(1,16)}=4.6 ; p<0.0469\right)$ but was unchanged in APP $\Delta$ CT15-KI (KI, $9.6 \pm 1.4 \%$; wt, $11.9 \pm 1.8 \%$; $\left.F_{(1,21)}=0.1, \mathrm{~ns}\right)$ and APPs $\alpha$-KI (KI, $7.1 \pm 1.6 \%$; wt, $10.5 \pm 1.2 \%$; $F_{(1,21)}=1.5$, ns). During the probe trial APP-KO mice as well as both KI lines showed a significant preference for the trained platform quadrant, regardless of genotype (Fig. $4 E$ ). In summary, 
both KI mutants (including the APPs $\alpha$ producing line) performed like wt controls and thus rescued the spatial navigation deficit of APP-KO mice.

\section{Impaired LTP in aged APP-KO mice is} rescued in APP-KI mutants

To determine whether the phenotype of the APP-KO and -KI lines in learning tasks correlates with alterations of synaptic plasticity, we performed electrophysiological recordings on acute hippocampal slices of the behaviorally tested individuals. First we tested for potential changes in basal synaptic transmission as such, focusing on field EPSP (fEPSP) size and paired pulse facilitation. In both KI lines, as well as in $\mathrm{KO}$ mice, basal synaptic transmission (expressed as the strength of responses to excitatory synaptic stimulation) was unaltered, as well as presynapse functionality, which was assessed by paired pulse facilitation (data not shown).

A classic model to study the cellular foundation of learning and memory in mammals is hippocampal LTP. In line with previous studies (Dawson et al., 1999; Seabrook et al., 1999) we observed that deletion of the APP gene causes a deficit in LTP in old age, paralleling the behavioral deficits. APP-KO mice showed a defect in the rate of induction and maintenance of LTP in the CA3/CA1 pathway of the hippocampus (Fig. 5). We recorded fEPSPs from 9- to 12-month-old mice and, after 20 min of baseline recording, induced LTP by theta burst stimulation (TBS; 10 trains of four pulses at $100 \mathrm{~Hz}$ with an interburst interval of $200 \mu \mathrm{s}$, repeated $3 \times$ ). Slices from APP-KO mice showed a significantly reduced potentiation $60 \mathrm{~min}$ after the TBS [wt mice, $212 \pm 14.5(n=15)$; APP-KO mice, $142.8 \pm 9.5(n=15) ; p<0.0013]$ (Fig. $5 A$ ). To assess whether LTP deficits observed for APP-KO mice might be attributable to functions mediated by the APP C terminus, we induced LTP in hippocampal slices of aged (12-15 months old) individuals of the two KI lines. We noticed that in this set of experiments the maximal potentiation obtained in wt mice was less than in wt animals of the APP-KO experiments, likely because of the increased age of KI mice. Yet, importantly, when we directly compared KI mice and their wt littermate controls (as had been done for the KO line), no LTP deficits were detectable in KI mice (Fig. $5 B, C$ ). Unlike APP-KO mice, aged APPs $\alpha$-KI mice showed unaltered LTP responses relative to their wt littermates after $60 \mathrm{~min}$ [wt, $141.97 \pm 5.25(n=22) ; \mathrm{KI}, 136.63 \pm 6.96$ $(n=35)]$. The same was true for aged

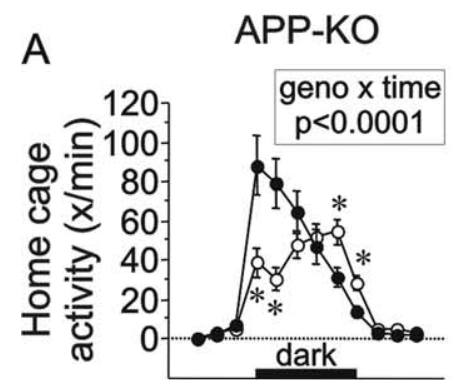

$\mathrm{APP} \triangle \mathrm{CT} 15-\mathrm{KI}$

APPs $\alpha-K I$

$2 \mathrm{~h}$ bins, begin at $00: 00$
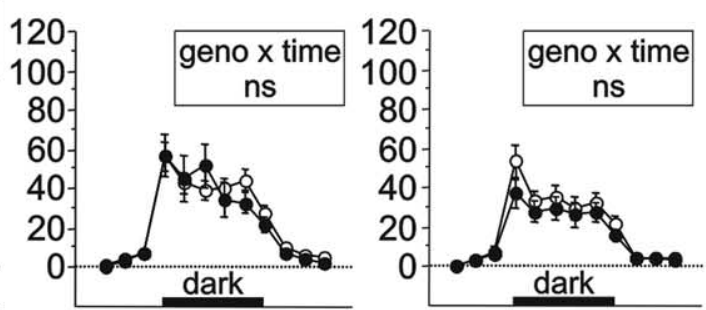

$B$
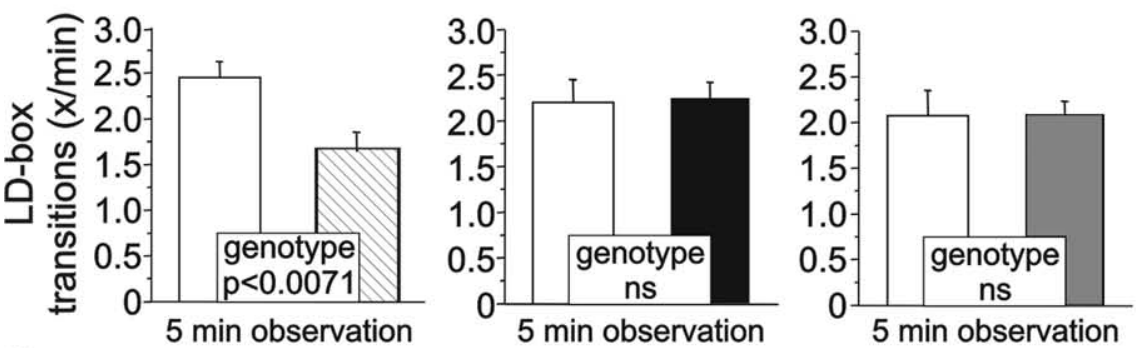

C
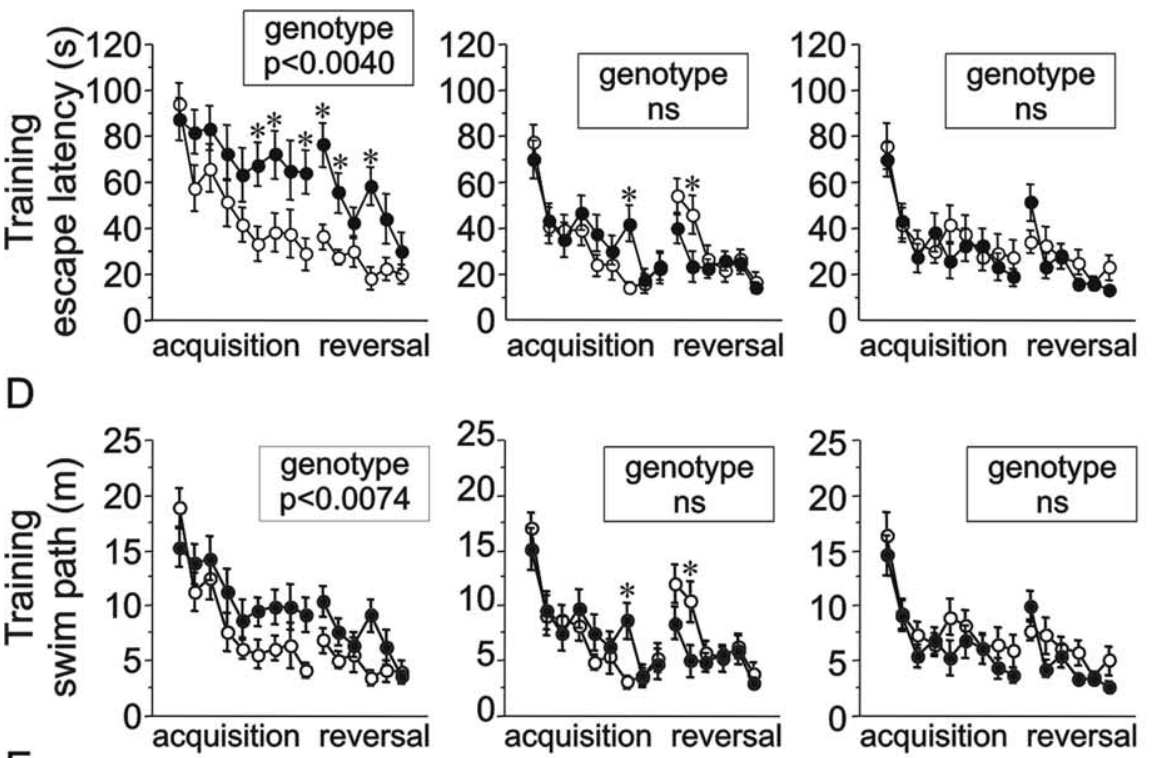

E
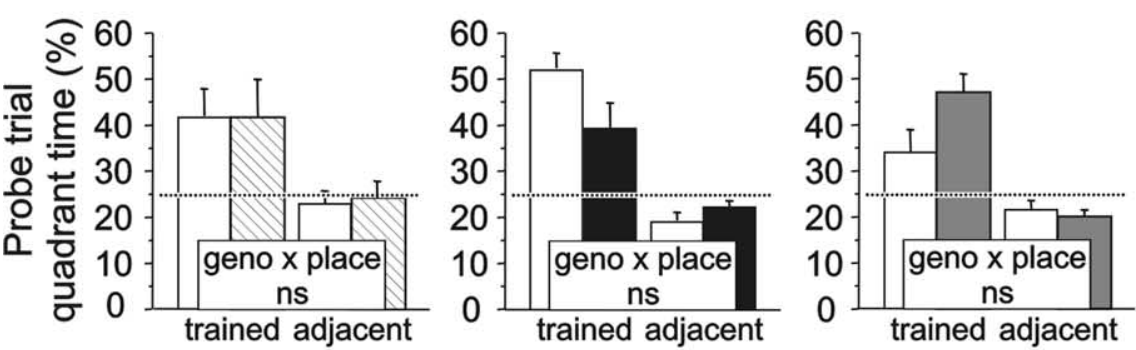

\section{wt littermates $\otimes$ APP-KO APP $\triangle \mathrm{CT} 15-\mathrm{KI} \bullet \mathrm{APP} \alpha-\mathrm{KI}$}

Figure 4. Home cage activity, explorative activity, and spatial learning. $\boldsymbol{A}$, In their home cages the APP-KO mice (13 KO and 14 wt) showed overshooting activity during the beginning of the dark phase. This effect was corrected in the APP $\Delta$ CT15-KI (15 KI and $12 \mathrm{wt}$ ) as well as in the APPs $\alpha$-KI line (15 KI and $18 \mathrm{wt})$. ANOVA: genotype $\times$ line, $F_{(2,73)}=1.0$, ns; genotype $\times$ time $\times$ line, $F_{(22,803)}=3.8(p<0.0001)$. APP-K0: genotype, $F_{(1,23)}=2.8$, ns; genotype $\times$ time, $F_{(11,253)}=10.3(p<0.0001)$. APP $\Delta$ CT15Kl: genotype, $F_{(1,23)}=0.1, \mathrm{~ns} ;$ genotype $\times$ time, $F_{(11,253)}=0.5$, ns. APPs $\alpha$-KI: genotype, $F_{(1,27)}=0.1$, ns; genotype $\times$ time, $F_{(11,297)}=0.5$, ns. $B$, In the light/dark box APP-KO mice showed significantly fewer transitions between the two compartments $\left(F_{(1,24)}=9.8 ; p<0.0071\right)$, indicative of reduced exploratory activity under aversive conditions. In contrast, both KI lines were statistically indistinguishable from wt littermate controls (APP $\Delta \mathrm{CT15-KI}, F_{(1,29)}=0.1$, ns; APPs $\alpha$-KI, (Figure legend continues) 
mice of the APP $\Delta$ CT15 line [wt, $131.92 \pm 6.07(n=16)$; KI, $124.94 \pm 6.45(n=22)]$. Although the absolute value of potentiation of $\sim 150 \%$ was somewhat lower when compared with the $\mathrm{APP}-\mathrm{KO} /$ wt recordings, the sensitivity was still high enough to detect potential differences of at least $15 \%$ between KI mice and their internal wt littermate controls (ANOVA; $p<0.05$ ). These results thus parallel the normal behavioral performance of KI mice, indicating again a rescue effect of both truncated APP polypeptides.

\section{Discussion}

In this study we have analyzed APP functional domains by using a reverse genetic in vivo approach and by introducing stop codons into the chromosomal APP locus in such a way that two different C-terminally truncated APP variants are expressed. We then compared the phenotype of KI mice with that of completely APP-deficient mice to delineate which portion of the APP molecule or which proteolytic fragments are essential for the various in vivo functions. We initially hypothesized that mice expressing the APP $\Delta$ CT15 variant, which is still processed and expressed at the cell surface, might resemble more closely the wt phenotype, whereas mice expressing solely APPs $\alpha$ might exhibit some deficits. The key finding of this study is that (although expressed at a slightly reduced level) both KI mutants grossly attenuate or completely rescue the defects observed in adult APP-KO mice. This finding is rather surprising because APP resembles a cell surface receptor. The numerous adaptor protein interactions with the APP C terminus rather suggested an APP signaling function in its full-length configuration or via AICD-mediated transcriptional regulation (for review, see Reinhard et al., 2005). Thus, at least with regard to the (postnatal) APP functions assessed by the tests used here, we have to refocus our attention to secreted APPs $\alpha$ that seems to be sufficient for normal brain weight and somatic growth, normal grip strength development, normal spontaneous home cage activity, normal exploratory activity, as well as normal spatial learning and LTP. This conclusion is further supported by recent studies from C. elegans, showing that expression of extracellular APL-1 fragments rescue the APL-1 KO phenotype (Hornsten et al., 2007). Future experiments will show whether APPs $\alpha$ might also be sufficient to rescue defects underlying the lethal phenotype of $\mathrm{APP}^{-/-} \mathrm{APLP}^{-/-}$mutants.

Our data suggest that the APP C terminus is dispensable for the physiological functions described above. It is also clear,

$\leftarrow$

$\left.F_{(1,29)}=0.1, \mathrm{~ns}\right) .(\mathrm{C}$, In the water maze place navigation task APP-K0 mice (13 K0 and $15 \mathrm{wt}$ ) took significantly longer than wt controls to find the hidden platform toward the end of acquisition training and during most of reversal training. Performance was similar to controls at the beginning and at the very end of testing. Neither APP $\Delta$ CT15-KI (17 KI and $16 \mathrm{wt}$ ) nor APPs $\alpha-\mathrm{KI}$ (17 KI and $16 \mathrm{wt}$ ) mice were impaired. APP $\Delta \mathrm{CT} 15-\mathrm{KI}$ had longer escape latencies during trial block 7 but were better than controls during trial block 11. ANOVA: genotype $\times$ line, $F_{(2,58)}=6.8(p<0.0022)$; genotype $\times$ time, $F_{(14,812)}=2.3(p<0.0051)$. APP-K0: genotype, $F_{(1,16)}=11.3(p<0.0040)$; genotype $\times$ time, $F_{(14,224)}=1.7(p<0.0662)$. APP $\Delta C\left(T 15-K 1\right.$ : genotype, $F_{(1,21)}=0.2$, ns; genotype $\times$ time, $F_{(14,294)}=1.9(p<0.0275)$. APPs $\alpha$-Kl: genotype, $F_{(1,21)}=0.1$, ns; genotype $\times$ time, $F_{(14,294)}=1.0, \mathrm{~ns}$. $D$, APP-KO mice also swam longer distances to reach the platform, whereas the two $\mathrm{KI}$ lines were unimpaired according to this criterion. APP $\triangle(\mathrm{T} 15-\mathrm{KI}$ had longer swim paths during trial block 7 but were better than controls during trial block 11. ANOVA: genotype $\times$ line, $F_{(2,58)}=4.6(p<0.0146)$; genotype $\times$ time, $F_{(14,812)}=2.0(p<0.0170)$. APP-K0: genotype, $F_{(1,16)}=9.4$ $(p<0.0074)$; time, $F_{(14,224)}=13.8(p<0.0001)$; genotype $\times$ time, $F_{(14,224)}=1.5$, ns. APP $\Delta$ CT15-Kl: genotype, $F_{(1,21)}=0.1$, ns; time, $F_{(14,294)}=10.9(p<0.0001)$; genotype $\times$ time, $F_{(14,294)}=1.8(p<0.0376)$. APPs $\alpha$-Kl: genotype, $F_{(1,21)}=1.0$, ns; time, $F_{(14,294)}=9.4(p<0.0001)$; genotype $\times$ time, $F_{(14,294)}=0.8$, ns. $E$, Probe trial performance was normal in all three lines. Time (percentage) spent in the trained quadrant was compared with average time (percentage) spent in the left and right adjacent quadrants. ANOVA: genotype $\times$ place $\times$ line, $F_{(2.58)}=0.9$, ns. APP-KO: place, $F_{(1,16)}=4.8(p<0.0433)$; genotype $\times$ place, $F_{(1,16)}=1.0$, ns. APP $\Delta\left(T 15-K l\right.$ : place, $F_{(1,21)}=20.6(p<0.0002)$; genotype $\times$ place, $F_{(1,16)}=1.3$, ns. APPs $\alpha$-Kl: place, $F_{(1,21)}=9.5(p<0.0056) ;$ genotype $\times$ place, $F_{(1,21)}=0.3$, ns. however, that it is crucial for APP processing and trafficking within the cell. Here we provide in vivo evidence that lack of the last 15 aa of endogenous APP markedly reduces A $\beta$ prouction. Reduced $\mathrm{A} \beta$ levels in brain were paralleled by a prosider reduced endosomal $\beta / \gamma$-cleavage of APP $\Delta C T 15$ as the most likely cause for reduced $\mathrm{A} \beta$ generation, because our data are well in agreement with previous in vitro studies that used truncated APP constructs in transfected cell lines (Koo and Reduced endocytosis leading to reduced $\mathrm{A} \beta$ production might be attributable to the lack of the endocytic YENP internalization signal itself (Perez et al., 1999) and/or attributable to the the low density lipoprotein receptor-related protein LRP (Pietrzik et al., 2004), and genetic deficiency of LRP in LRP-KO surved here for the APP $\Delta C T 15$ deletion. Recently, studies have may play a beneficial physiological role, e.g., by limiting neuronal excitation (Kamenetz et al., 2003). From our study we can exclude that deficits observed for APP-KO mice are attribAPPs $\alpha$-KI mice.

With regard to the growth and brain weight deficit that can be rescued by $\operatorname{APPs} \alpha$, it is interesting to note that in vitro cytes as well as certain fibroblast lines (Saitoh et al., 1989). APPs $\alpha$ functions synergistically with epidermal growth factor as a growth factor for neuronal progenitor cells in the subvenand (Phinney et al., 1999; Herms et al., 2004; Priller et cortex or hippocampus of adult APP-KO mice, and at present

Previously, experiments that used anti-APP antibodies to block protein function or antisense oligonucleotides have supported a role for APP in learning and memory (Turner et al., 2003), although the interpretation has been hampered by the fact that the antibodies used cannot distinguish between APPs and full-length APP and also may have crossreacted with APLPs. Here we have shown that the defect in Morris water maze acquisition learning of adult APP-KO mice is corrected in mice expressing solely either APPs $\alpha$ or APP $\Delta$ CT15 (which is processed readily by $\alpha$-secretase). During training APP-KO mice displayed considerably delayed learning, evidenced by less rapid reductions in escape latency and swim path length. The overall performance deficit resulted from a combination of a true learning deficit (as evidenced by increased thigmotaxis, less efficient orientation toward the platform, and increased swim path length) and a motor impairment (as shown by reduced swim speed). APP-KI variants completely rescued the learning 
A

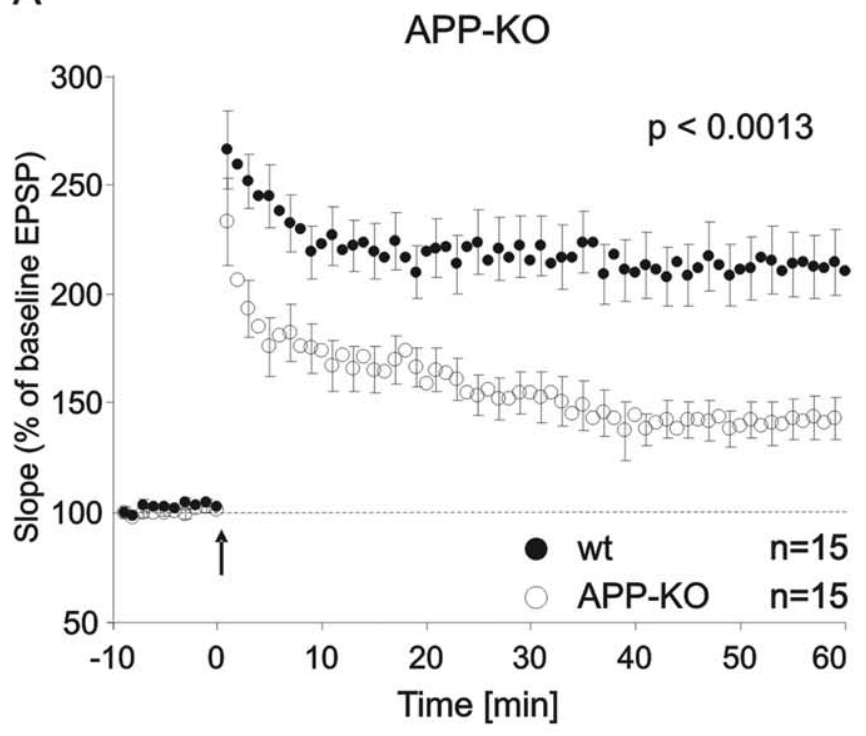

B

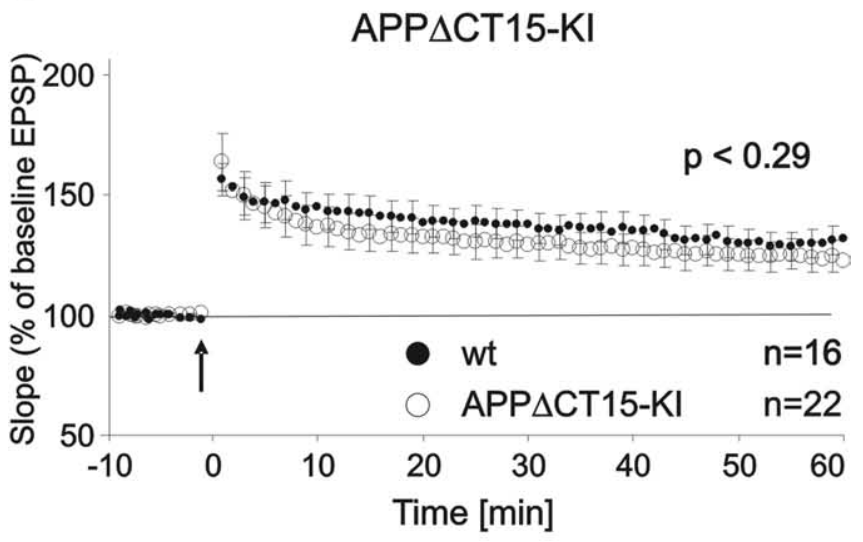

C

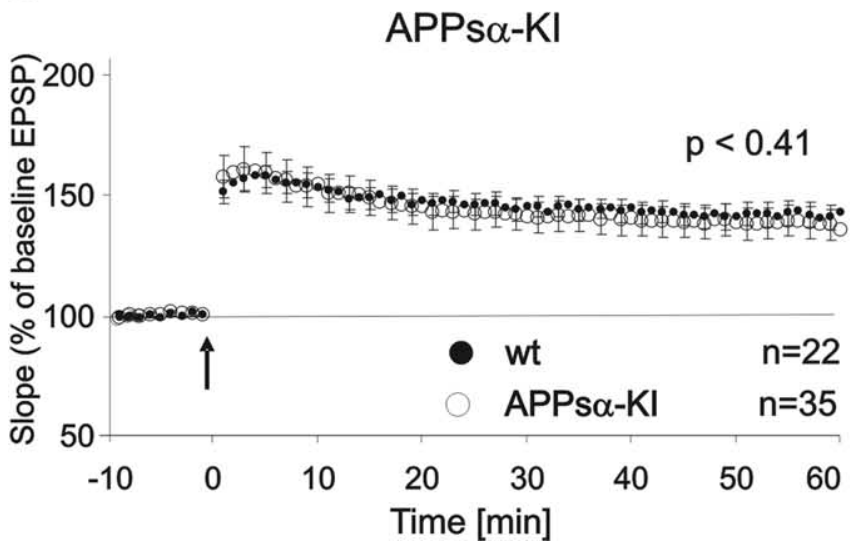

Figure 5. LTP analysis in APP-KI. LTP of fEPSPs was induced in hippocampal slices by TBS (10 trains of 4 pulses at $100 \mathrm{~Hz}$ with an interburst interval of $200 \mu \mathrm{s}$, repeated $3 \times$ ) after 20 min of $0.1 \mathrm{~Hz}$ test stimulation (arrow). $\boldsymbol{A}$, Aged APP-KO mice (9-12 months) showed significantly lower rates of induction and maintenance of LTP than their wt littermates, expressed as a percentage of the mean slope before LTP induction (baseline). On testing for $60 \mathrm{~min}$ after TBS, the APP-K0 mice showed a significantly reduced potentiation [Wt, $212 \pm 14.5(n=15) ; A P P-K 0,142.8 \pm 9.5(n=15) ; p<$ 0.0013]. $\boldsymbol{B}$, Unlike APP-K0 mice, aged APP $\Delta$ CT15-KI mice (12-15 months) did not have LTP deficits relative to their wt littermates after $60 \mathrm{~min}$ [wt, $131.92 \pm 6.07(n=16)$; APP $\Delta$ CT15-Kl, $124.94 \pm$ $6.45(n=22)]$. C, Neither did aged APPs $\alpha$-KI mice show deficits in induction or maintenance of LTP after 60 min when compared with wt control animals [wt, $141.97 \pm 5.25(n=22) ; A P P s \alpha-K L$, $136.63 \pm 6.96(n=35)$; filled circles, wt animals; open circles, Kl animals]. All data are presented as the means \pm SEM; Student's t test. deficit and attenuated the physical impairment to a level that no longer had a detectable effect on training performance. APP deficiency did, however, not affect spatial memory per se as evidenced by normal probe trial scores of the relatively young $(2.4$ months old) APP-KO mice studied here. Because animals that have undergone water maze testing once are not naive any longer, we could not assess whether aged mice would display, in addition to learning deficits, impairments in memory as observed in previous studies (Phinney et al., 1999; Seabrook et al., 1999). Instead, we studied synaptic plasticity in aged mice to assess potentially correlated impairments. In summary, our behavioral data provide compelling genetic evidence that APPs $\alpha$ is the principal APP fragment that is limiting in the compromised spatial learning performance of APP-KO mice. This is consistent with and extends previous studies showing that exogenous recombinant APPs $\alpha$ (recAPPs $\alpha$ ) injected into the brain of wt mice can enhance memory in certain behavioral paradigms (Meziane et al., 1998; Bour et al., 2004). In this regard it is interesting that recently the infusion of recAPPs $\alpha$ and ADAM10 overexpression was shown to lead to increased cortical synaptogenesis (Bell et al., 2007).

As a novel phenotype we report here that APP-KO mice display altered circadian locomotor activity with increased agitation at the onset of the dark period, reminiscent of the altered rhythms of activity and restlessness observed in AD patients (Reisberg et al., 1987). Again, this deficit is rescued in APP-KI mice, suggesting that a deficit in APPs $\alpha$ levels may contribute to the noncognitive behavioral symptoms in AD. APP-KO mice are known to exhibit reduced activity when placed in a novel environment (Zheng et al., 1995). This was confirmed in the light/dark box test of the present study in which the number of light/dark transitions was reduced in APP-KO mice. Again this deficit was rescued fully in both KI lines.

APP release may occur constitutively but also is induced by neuropeptides and neuronal activity, by agonist-mediated stimulation of neurotransmitter receptors (Turner et al., 2003), and after the in vivo induction of LTP in the dentate gyrus of anesthetized rats (Fazeli et al., 1994). In addition, preincubation of hippocampal slices with APPs $\alpha$ has been shown to facilitate (high frequency-induced) LTP in the CA1 region and to modulate long-term depression (Ishida et al., 1997). However, up to now the role of endogenously produced APPs $\alpha$ for induction and maintenance of LTP has remained elusive. Our study now corroborates that the LTP defect observed for APP-KO mice is attributable to a loss of physiological APPs $\alpha$ functions and not attributable to other confounding effects, including reactive gliosis and axodendritic abnormalities as previously hypothesized (Seabrook et al., 1999). Interestingly, both memory and LTP deficits that occur as a consequence of APP (and thus APPs $\alpha$ ) deficiency are age-dependent (Dawson et al., 1999; Seabrook et al., 1999), suggesting that compensatory mechanisms that may mask the APPs $\alpha$ deficit in young mice are lost during the aging process. Intriguingly, reduced APPs levels not only have been found in the CSF of aged rats, which correlated with spatial memory deficits (Anderson et al., 1999), but also were found to be reduced in the CSF of affected members of a familial case of AD (Almkvist et al., 1997). Moreover, reduced CSF levels of APPs $\alpha, \alpha$-secretase ADAM10 protein level, and activity are prominent features of sporadic AD cases (Lannfelt et al., 1995; Sennvik et al., 2000; Colciaghi et al., 2002; Tyler et al., 2002). Together, these studies and our data highlight the functional importance of endogenous APPs $\alpha$ for learning and neuronal plasticity as well as circadian locomotor activity. This suggests that loss of APPs $\alpha$ may contribute more directly to the development of symptoms and the 
pathogenesis of $\mathrm{AD}$ than previously anticipated and lends additional support to the concept of increasing $\alpha$-secretase activity as an $\mathrm{AD}$ treatment.

\section{References}

Almkvist O, Basun H, Wagner SL, Rowe BA, Wahlund LO, Lannfelt L (1997) Cerebrospinal fluid levels of alpha-secretase-cleaved soluble amyloid precursor protein mirror cognition in a Swedish family with Alzheimer disease and a gene mutation. Arch Neurol 54:641-644.

Anderson JJ, Holtz G, Baskin PP, Wang R, Mazzarelli L, Wagner SL, Menzaghi F (1999) Reduced cerebrospinal fluid levels of alpha-secretasecleaved amyloid precursor protein in aged rats: correlation with spatial memory deficits. Neuroscience 93:1409-1420.

Anliker B, Müller U (2006) The functions of the mammalian amyloid precursor protein and related amyloid precursor-like proteins. Neurodegener Dis 3:239-246.

Bell KF, Zheng L, Fahrenholz F, Cuello AC (2007) ADAM-10 overexpression increases cortical synaptogenesis. Neurobiol Aging, in press.

Bour A, Little S, Dodart JC, Kelche C, Mathis C (2004) A secreted form of the beta-amyloid precursor protein $\left(\mathrm{sAPP}_{695}\right)$ improves spatial recognition memory in OF1 mice. Neurobiol Learn Mem 81:27-38.

Caillé I, Allinquant B, Dupont E, Bouillot C, Langer A, Müller U, Prochiantz A (2004) Soluble form of amyloid precursor protein regulates proliferation of progenitors in the adult subventricular zone. Development 131:2173-2181.

Chyung JH, Selkoe DJ (2003) Inhibition of receptor-mediated endocytosis demonstrates generation of amyloid beta-protein at the cell surface. J Biol Chem 278:51035-51043.

Colciaghi F, Borroni B, Pastorino L, Marcello E, Zimmermann M, Cattabeni F, Padovani A, Di Luca M (2002) $\alpha$-Secretase ADAM10 as well as $\alpha$ APPs is reduced in platelets and CSF of Alzheimer disease patients. Mol Med 8:67-74.

Dawson GR, Seabrook GR, Zheng H, Smith DW, Graham S, O'Dowd G, Bowery BJ, Boyce S, Trumbauer ME, Chen HY, van der Ploeg LH, Sirinathsinghji DJ (1999) Age-related cognitive deficits, impaired long-term potentiation and reduction in synaptic marker density in mice lacking the beta-amyloid precursor protein. Neuroscience 90:1-13.

Duff K, Eckman C, Zehr C, Yu X, Prada CM, Perez-Tur J, Hutton M, Buee L, Harigaya Y, Yager D, Morgan D, Gordon MN, Holcomb L, Refolo L, Zenk B, Hardy J, Younkin S (1996) Increased amyloid- $\beta$ 42(43) in brains of mice expressing mutant presenilin 1. Nature 383: $710-713$.

Fazeli MS, Breen K, Errington ML, Bliss TV (1994) Increase in extracellular NCAM and amyloid precursor protein following induction of long-term potentiation in the dentate gyrus of anaesthetized rats. Neurosci Lett 169:77-80.

Grimm MO, Grimm HS, Patzold AJ, Zinser EG, Halonen R, Duering M, Tschäpe JA, De Strooper B, Müller U, Shen J, Hartmann T (2005) Regulation of cholesterol and sphingomyelin metabolism by amyloid-beta and presenilin. Nat Cell Biol 7:1118-1123.

Heber S, Herms J, Gajic V, Hainfellner J, Aguzzi A, Rülicke T, von Kretzschmar H, von Koch C, Sisodia S, Tremml P, Lipp HP, Wolfer DP, Müller U (2000) Mice with combined gene knock-outs reveal essential and partially redundant functions of amyloid precursor protein family members. J Neurosci 20:7951-7963.

Hebert SS, Serneels L, Tolia A, Craessaerts K, Derks C, Filippov MA, Müller U, De Strooper B (2006) Regulated intramembrane proteolysis of amyloid precursor protein and regulation of expression of putative target genes. EMBO Rep 7:739-745.

Herms J, Anliker B, Heber S, Ring S, Fuhrmann M, Kretzschmar H, Sisodia S, Müller U (2004) Cortical dysplasia resembling human type 2 lissencephaly in mice lacking all three APP family members. EMBO J 23:4106-4115.

Hornsten A, Lieberthal J, Fadia S, Malins R, Ha L, Xu X, Daigle I, Markowitz M, O'Connor G, Plasterk R, Li C (2007) APL-1, a Caenorhabditis elegans protein related to the human beta-amyloid precursor protein, is essential for viability. Proc Natl Acad Sci USA 04:1971-1976.

Ishida A, Furukawa K, Keller JN, Mattson MP (1997) Secreted form of betaamyloid precursor protein shifts the frequency dependency for induction of LTD and enhances LTP in hippocampal slices. NeuroReport 8:2133-2137.
Kamenetz F, Tomita T, Hsieh H, Seabrook G, Borchelt D, Iwatsubo T, Sisodia S, Malinow R (2003) APP processing and synaptic function. Neuron 37:925-937.

Koo EH, Squazzo SL (1994) Evidence that production and release of amyloid beta-protein involves the endocytic pathway. J Biol Chem 269:17386-17389.

Lannfelt L, Basun H, Wahlund LO, Rowe BA, Wagner SL (1995) Decreased alpha-secretase-cleaved amyloid precursor protein as a diagnostic marker for Alzheimer's disease. Nat Med 1:829-832.

Li ZW, Stark G, Götz J, Rülicke T, Gschwind M, Huber G, Müller U, Weissmann C (1996) Generation of mice with a 200-kb amyloid precursor protein gene deletion by Cre recombinase-mediated sitespecific recombination in embryonic stem cells. Proc Natl Acad Sci USA 93:6158-6162.

Madani R, Kozlov S, Akhmedov A, Cinelli P, Kinter J, Lipp HP, Sonderegger P, Wolfer DP (2003) Impaired explorative behavior and neophobia in genetically modified mice lacking or overexpressing the extracellular serine protease inhibitor neuroserpin. Mol Cell Neurosci 23:473-494.

Magara F, Müller U, Li ZW, Lipp HP, Weissmann C, Stagljar M, Wolfer DP (1999) Genetic background changes the pattern of forebrain commissure defects in transgenic mice underexpressing the $\beta$-amyloid precursor protein. Proc Natl Acad Sci USA 96:4656-4661.

Meziane H, Dodart JC, Mathis C, Little S, Clemens J, Paul SM, Ungerer A (1998) Memory-enhancing effects of secreted forms of the beta-amyloid precursor protein in normal and amnestic mice. Proc Natl Acad Sci USA 95:12683-12688.

Müller U, Cristina N, Li ZW, Wolfer DP, Lipp HP, Rülicke T, Brandner S, Aguzzi A, Weissmann C (1994) Behavioral and anatomical deficits in mice homozygous for a modified beta-amyloid precursor protein gene. Cell 79:755-765.

Perez RG, Soriano S, Hayes JD, Ostaszewski B, Xia W, Selkoe DJ, Chen X, Stokin GB, Koo EH (1999) Mutagenesis identifies new signals for $\beta$-amyloid precursor protein endocytosis, turnover, and the generation of secreted fragments, including $\mathrm{A} \beta 42$. J Biol Chem 274:18851-18856.

Phinney AL, Calhoun ME, Wolfer DP, Lipp HP, Zheng H, Jucker M (1999) No hippocampal neuron or synaptic bouton loss in learning-impaired aged beta-amyloid precursor protein-null mice. Neuroscience 90:1207-1216.

Pietrzik CU, Busse T, Merriam DE, Weggen S, Koo EH (2002) The cytoplasmic domain of the LDL receptor-related protein regulates multiple steps in APP processing. EMBO J 21:5691-5700.

Pietrzik CU, Yoon IS, Jaeger S, Busse T, Weggen S, Koo EH (2004) Fe65 constitutes the functional link between the low-density lipoprotein receptor-related protein and the amyloid precursor protein. J Neurosci 24:4259-4265.

Priller C, Bauer T, Mitteregger G, Krebs B, Kretzschmar HA, Herms J (2006) Synapse formation and function is modulated by the amyloid precursor protein. J Neurosci 26:7212-7221.

Reinhard C, Hebert SS, De Strooper B (2005) The amyloid-beta precursor protein: integrating structure with biological function. EMBO J 24:3996-4006.

Reisberg B, Borenstein J, Salob SP, Ferris SH, Franssen E, Georgotas A (1987) Behavioral symptoms in Alzheimer's disease: phenomenology and treatment. J Clin Psychiatry [Suppl] 48:9-15.

Saitoh T, Sundsmo M, Roch JM, Kimura N, Cole G, Schubert D, Oltersdorf T, Schenk DB (1989) Secreted form of amyloid beta protein precursor is involved in the growth regulation of fibroblasts. Cell 58:615-622.

Seabrook GR, Smith DW, Bowery BJ, Easter A, Reynolds T, Fitzjohn SM, Morton RA, Zheng H, Dawson GR, Sirinathsinghji DJ, Davies CH, Collingridge GL, Hill RG (1999) Mechanisms contributing to the deficits in hippocampal synaptic plasticity in mice lacking amyloid precursor protein. Neuropharmacology 38:349-359.

Selkoe DJ (2004) Cell biology of protein misfolding: the examples of Alzheimer's and Parkinson's diseases. Nat Cell Biol 6:1054-1061.

Sennvik K, Fastbom J, Blomberg M, Wahlund LO, Winblad B, Benedikz E (2000) Levels of alpha- and beta-secretase-cleaved amyloid precursor protein in the cerebrospinal fluid of Alzheimer's disease patients. Neurosci Lett 278:169-172. 
Steinbach JP, Müller U, Leist M, Li ZW, Nicotera P, Aguzzi A (1998) Hypersensitivity to seizures in beta-amyloid precursor protein-deficient mice. Cell Death Differ 5:858-866.

Tremml P, Lipp HP, Müller U, Ricceri L, Wolfer DP (1998) Neurobehavioral development, adult open field exploration and swimming navigation learning in mice with a modified beta-amyloid precursor protein gene. Behav Brain Res 95:65-76.

Turner PR, O'Connor K, Tate WP, Abraham WC (2003) Roles of amyloid precursor protein and its fragments in regulating neural activity, plasticity, and memory. Prog Neurobiol 70:1-32.

Tyler SJ, Dawbarn D, Wilcock GK, Allen SJ (2002) $\alpha$ - and $\beta$-secretase: profound changes in Alzheimer's disease. Biochem Biophys Res Commun 299:373-376.

von Koch CS, Zheng H, Chen H, Trumbauer M, Thinakaran G, van der Ploeg
LH, Price DL, Sisodia SS (1997) Generation of APLP2 KO mice and early postnatal lethality in APLP2/APP double KO mice. Neurobiol Aging 18:661-669.

White AR, Reyes R, Mercer JF, Camakaris J, Zheng H, Bush AI, Multhaup G, Beyreuther K, Masters CL, Cappai R (1999) Copper levels are increased in the cerebral cortex and liver of APP and APLP2 knockout mice. Brain Res 842:439-444.

Zheng H, Koo EH (2006) The amyloid precursor protein: beyond amyloid. Mol Neurodegener 1:5.

Zheng H, Jiang M, Trumbauer ME, Sirinathsinghji DJ, Hopkins R, Smith DW, Heavens RP, Dawson GR, Boyce S, Conner MW, Stevens KA, Slunt HH, Sisodia SS, Chen HY, van der Ploeg LH (1995) $\beta$-Amyloid precursor protein-deficient mice show reactive gliosis and decreased locomotor activity. Cell 81:525-531. 